\title{
PREVALENCE OF SARCOCYSTS AND IT'S ASSOCIATED CHEMICAL CHANGES IN CATTLE'S MEAT IN ALEXANDRIA GOVERNORATE
}

\author{
AMANY FARAG ZAYED*; KAREMA MOHAMED EL-BAKRY ${ }^{* *}$ and ENAS A.H. FARAG ${ }^{* * *}$ \\ * Food hygiene ** Parasitology *** Biochemistry and food deficiency. Animal Health Research Institute, Alexandria \\ and Banah
}

\section{ABSTRACT}

Received at: 13/6/2012

Accepted: $18 / 7 / 2012$
The prevalence of grossly apparent Sarcocystes and its relation to the analytic of infected meat was investigated in Alexandria abattoirs through a period of six month. A total of 172 native bread cattle were used for these studied. 40.12 of cattle under investigation were infected with Sarcocysts Fusiformis. The incidence of different organs was highest in the esophagus (36.4\%) however the lowest rate was reported in the heart $(13.0 \%)$. Infection with Sarcocysts Fusiformis lead to an increase in the moisture percent and $\mathrm{pH}$ value and a decrease in both protein and fat percentages, such effect seriously lower the meat quality.

Key words: Sarcocysts, Oesophagus, $P H$.

\section{INTRODUCTION}

Parasitic diseases were the most important serious problem among animal. It is not only affected general health condition of the animals but it could been also a zoontic diseases transmitted to human being. Sarcocysts infection is common in buffaloes worldwide as nearly all adult buffaloes are infected with some Sarcocysts species in certain countries as India (Dubey et al., 1989). Sarcocystis species are the most common parasites of domestic ruminants that utilize vertebrates as both intermediate host and definitive host. (Guclu et al., 2004).

Some species of Sarcocysts can be severely pathogenic to farm animals, causing anorexia, weight-loss, abortion and even death. But perhaps because Sarcocysts are so common they have frequently been regarded as innocuous. Even in the USA and UK, many cases of abortion in farm animals go undiagnosed, and it is only now that sarcocystosis is being implicated as potentially of economic importance to the farm industry. In many cases however, the major effect is likely to be subclimcal, seen in farm animals only as a reduction in live weight gain (Herbert and Smith, 1987).

Man may be involved as final or intermediate host in the life cycle of several Sarcocystis which infect man. Sarcocystis suihominis and S.hominis infect man as a final host while S.lindermanni as an intermediate host (Jae-Woong et al., 1988).

Sarcocystis hominis is only mild pathogenic in humans, causing nausea, stomach pain and diarrhea (Dubey et al., 1989). The prevalence of intestinal sarcocystosis in humans is low and is only rarely associated with illness (Ronald, 2004)

Sarcocysts remains viable for long periods of time and that proper heating and freezing may be effective controls and considered harmless in cooked meat, nevertheless a low prevalence can be included among quality parameters as an indication of good sanitation of the meat (Gabriele et al., 2006).

Carcasses heavily infected with Sarcocysts are totally rejected, but that of light infection, can pass for human consumption after partial trimming without restriction.

The question raised is that is this meat pass for human consumption after partial trimming of the parts contained the Sarcocysts have the same quality of meat obtained from healthy non infected animals?

This study aimed to determined the prevalence of Sarcocyst in different Alexanderia abattoirs and to compare the quality of meat from infected and non infected animals using chemical parameters.

\section{MATERIALS and METHODS}

\section{1- Collction of samples:}

A proper system of identification were adopted with carcasses of 172 cattle at 4 of a local abattoirs in Alexandria to facilitate the through routine post mortem examination aiming to reveal the infection with macroscopic cysts. Muscular samples were excised and submitted to the lab for further investigation. Each carcass was represented by a group of muscle samples from tongue, oesophagus, cervical (sloat), diaphragm and heart muscles.

\section{2- Preperation of samples:}

Muscular samples with macroscopically visible Sarcocysts were identified according to (Soulsby, 1986), then cut from other muscular tissues mentioned. 


\section{3- Histopathological examination:}

The samples were fixed in neutral buffered $10 \%$ formalin, processed by standard histological techniques, sectioned at $5 \mathrm{~mm}$. stained by haematoxylin and eosin, and examined by light microscope for the presence of Sarcocysts. The differentiation between the microscopic species was based on the morphological criteria (size and cyst wall) described by (Dubey et al., 1989).

\section{4- Chemical Examination:}

1- Determination of $\mathrm{pH}$ was carried out as outlined by (Pearson, 1984)

2- Determination of protein percentage was carried out as outlined by (AOAC, 1980).

3- Determination of fat percentage was carried out as outlined by (AOAC, 1980)

4- Determination of ash percentage was carried out as outlined by (AOAC, 1980)

5- Determination of moisture percentage was carried out as outlined by (FAO, 1986).

\section{RESULTS}

\section{Macroscopical examination:}

Macroscopic cysts appeared grossly as spindle shaped white or creamy in color. Cysts measured 10.0-45.0 mm length \&1.5-7.0 mm width. Fig. (1-4)

\section{Histopathologic features:}

Stained smears revealed banana shaped bradyzoites
(Sarcocyst Fusiformis.). The submitted sections contained few intermyofibrillar protozoal cysts. The diameter of every cyst ranged from 2-4 $\mathrm{mm}$ and was lined by a thick wall (100 microns) (fig.5). The cyst contained myriads numbers of nucleated bananashaped zoites (Fig.6).

The incidence of macroscopic Sarcocyst Fusiformis in slaughtered animals in abattoirs at Alexandria Governorate were represented in Table (1). The incidence of macroscopic Sarcocyst Fusiformis in some organs including tongue, esophagus cervical muscles, diaphragm and heart were shown in Table (2).

\section{Chemicals analysis of meat infected with \\ Sarcocysts:}

Table (3) show that total fat \% were significantly lower in infected samples than non-infected one._Data recorded in (Table 4) revealed highly significant reduction in the total protein percent in meat samples infected with Sarcocysts Fusiformis. in comparison with non-infected meat samples. Data in (Table 5) revealed that the ash \% was higher in infected samples than non infected ones. Results recorded in From the results recorded in (Table 6) there is highly significant increase of the $\mathrm{pH}$ value in infected meat samples. (Table 7) showed that the moisture percent were significantly higher in infected samples than non-infected ones.

Table 1: Incidence of macroscopic Sarcocysts Fusiformis. in slaughtred cattle at different abattoirs at Alexandria Governorates.

\begin{tabular}{lccc}
\hline $\begin{array}{l}\text { Abattoirs at Alexandria } \\
\text { Governorates }\end{array}$ & No. of examined animals & No. of infested animals & \% of infestation \\
\hline America & 48 & 20 & 11.63 \\
\hline Abo-Keer & 51 & 26 & 15.12 \\
\hline El-Salam & 43 & 15 & 8.72 \\
\hline $\begin{array}{l}\text { Faculty of Agriculture } \\
\text { Alex.Univ. }\end{array}$ & 30 & 8 & 4.65 \\
\hline Total & 172 & 69 & 40.12 \\
\hline
\end{tabular}

Table 2: Prevalence of macroscopic Sarcocysts Fusiformis. in different muscular tissues of slaughtered cattle $(n=69)$.

\begin{tabular}{lcc}
\hline \multicolumn{1}{c}{ Muscular tissue } & No. infected organs & \% of infestation \\
\hline Tongue & 18 & $25.1 \%$ \\
\hline Oesophagus & 26 & $36.4 \%$ \\
\hline Cervical muscles & 20 & $27.8 \%$ \\
\hline Diaphragm & 14 & $20.3 \%$ \\
\hline Heart & 9 & $13.0 \%$ \\
\hline
\end{tabular}

Table 3: Statistical analytical results of fat percent in the examined cattle's organs non-infected and infected with macroscopic Sarcocysts Fusiformis.

\begin{tabular}{lcccc}
\hline Samples & No. & Min. & Max. & Mean \pm S.E. \\
\hline Non infected samples & 103 & 0.73 & 3.36 & $2.44 \pm 0.154$ \\
\hline Infected sample & 69 & 0.33 & 2.11 & $1.46 \pm 0.127^{* *}$ \\
\hline
\end{tabular}

** highly significant difference 
$\underline{\text { Assiut Vet. Med. J. Vol. } 58 \text { No. } 134 \text { July } 2012}$

Table 4: Statistical analytical results of protein percent in the examined non-infected and infected cattle's organs with macroscopic Sarcocysts Fusiformis.

\begin{tabular}{lcccc}
\hline Samples & No. & Min. & Max. & Mean \pm S.E. \\
\hline Non infected samples & 103 & 14.99 & 16.56 & $15.86 \pm 0.443$ \\
\hline Infected sample & 69 & 11.34 & 15.97 & $14.11 \pm 0.123^{* *}$ \\
\hline
\end{tabular}

** highly significant difference

Table 5: Statistical analytical results of ash percent in the examined non-infected and infected cattle's organs with macroscopic Sarcocysts Fusiformis.

\begin{tabular}{lcccc}
\hline Samples & No. & Min. & Max. & Mean \pm S.E. \\
\hline Non infected samples & 103 & 0.89 & 1.20 & $1.15 \pm 0.010$ \\
\hline Infected sample & 69 & 1.02 & 1.87 & $1.45 \pm 0.016^{* *}$ \\
\hline
\end{tabular}

** highly significant difference

Table 6: Statistical analytical results of $\mathrm{pH}$ values in the examined cattle's organs non-infected and infected with macroscopic Sarcocysts Fusiformis.

\begin{tabular}{lcccc}
\hline Samples & No. & Min. & Max. & Mean \pm S.E. \\
\hline Non infected samples & 103 & 5.02 & 5.98 & $5.25 \pm 0.023$ \\
\hline Infected sample & 69 & 5.91 & 6.07 & $5.99 \pm 0.012 * *$ \\
\hline
\end{tabular}

** Highly significant difference

Table 7: Statistical analytical results of moisture percent in the examined cattle's organs non-infected and infected with macroscopic Sarcocysts Fusiformis.

\begin{tabular}{lllll}
\hline Samples & No. & Min. & Max. & Mean \pm S.E. \\
\hline Non infected samples & 103 & 73.87 & 80.45 & $76.99 \pm 0.287$ \\
\hline Infected sample & 69 & 76.12 & 85.89 & $80.98 \pm 0.225^{* *}$ \\
\hline
\end{tabular}

** Highly significant difference

\section{Macroscopical finding of Sarcocysts in different tissues :-}

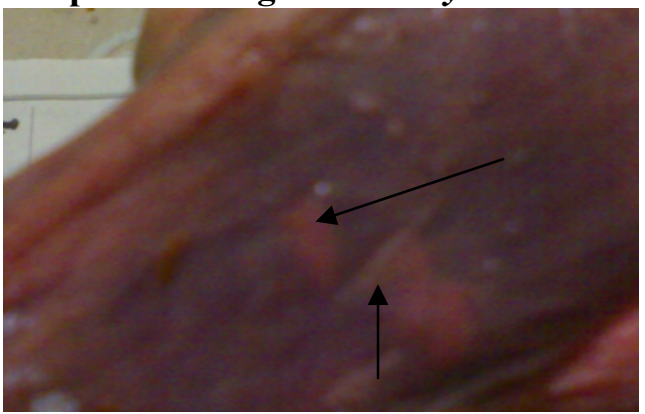

Fig. (1) Sarcocyst in cervical muscle

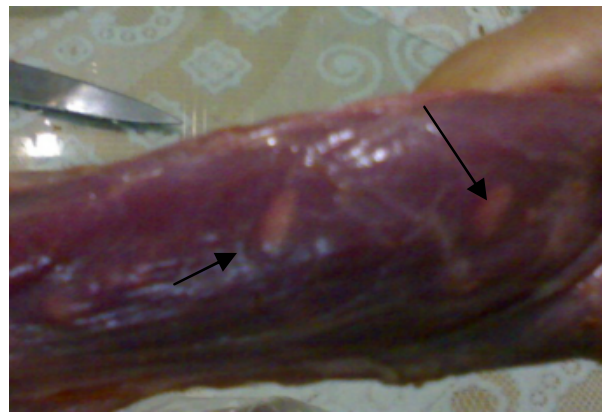

Fig. (2) Sarcocysts in Oesophagus

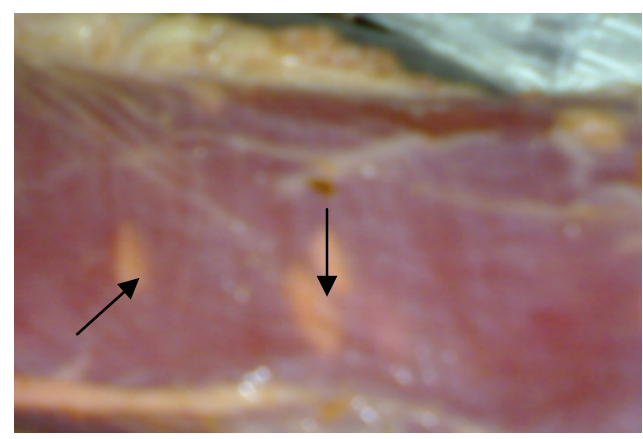

Fig. (3) Sarcocysts in diaphgram 


\section{Microscopical features: \\ Specimen: Skeletal muscles}

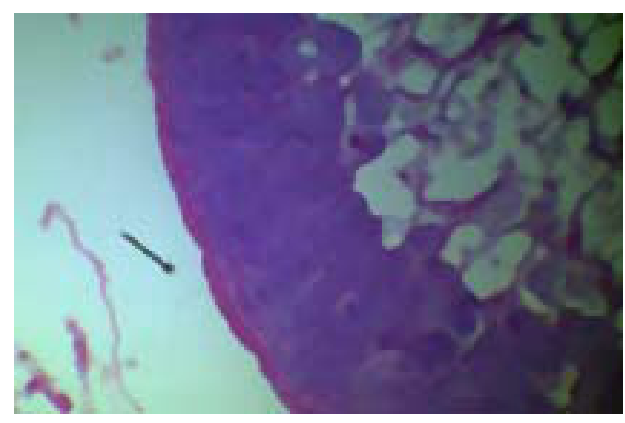

Fig. 4: (Skeletal muscles) A protozoal cyst lined with a thick wall (arrow) and myriads of protozoal zoites (arrow head). HE $=100$.

\section{DISCUSSION}

Results recorded in Table (1) revealed that macroscopic Sarcocystis were reported in 69 out of $172(40.12 \%)$ of slaughtered cattle in different abattoirs at Alexandria Governorates, El-Sayed, (2010) reported $17.2 \%$ of infection with macroscopic Sarcocysts in slaughtered cattle at the age of 2-3 years old, and $68.1 \%$ of infection with macroscopic Sarcocysts at the age over 5 years old.

Table (2) showed the highest percent of infection in organs with macroscopic Sarcocysts in oesophagus (36.4\%) and the lowest in the heart (13\%). A similar results were obtained by Latif et al. (1999); Vercruysse et al. (1989) and Yassien et al. (2006).

Macroscopic cysts appear grossly as spindle shaped white or creamy in color. Cysts measured 10.0-45.0 $\mathrm{mm}$ length \&1.5-7.0 $\mathrm{mm}$ width. Stained smears revealed banana shaped bradyzoites.( Sarcocysts Fusiformis) this results was in agreement with (ElSayed, 2010).

A highly significant reduction were reported in the total protein percent in meat samples infected with Sarcocysts Fusiformis in comparison with noninfected meat samples, these findings might be attributed to the adverse effect of such parasite on muscles constituents resulting from oedema and mayositis which lower muscular protein (Alan and Mac, 1996).

A highly significantly lowering in fat $\%$ in Sarcocysts infected infected animals compared to those of the non infected ones were recorded. Those finding was due to weakness and loss of appetite of infected animals consequently excessive utilization of body fat (Dubey et al., 1982).

Ash \% was highly significantly increased in Sarcocysts infected cattle compared to those of non infected. This may be attributed to the relative decrease in the dry matters (protein, fat) in infected animals as a result of lipolysis and proteolysis and consequently increase in the inorganic matter

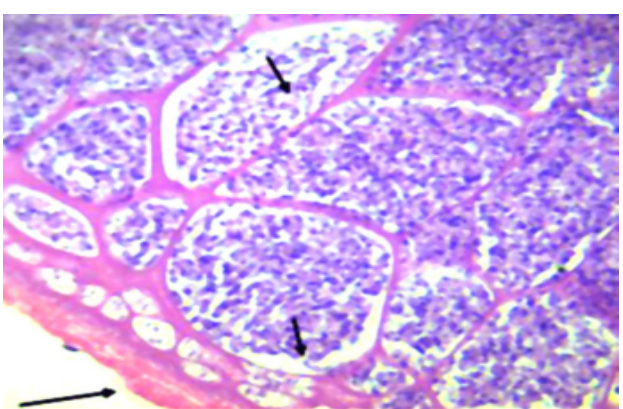

Fig. 5: Higher magnification of fig. 1 to show the wall (arrow) and the Banana-shaped zoites (arrow) $\mathrm{HE}=100$

concentration which is considered the main component of ash (Awad, and Georgy, 1984).

A highly significant increase in the moisture percent were reported in Sarcocysts infected cattle compared to those non infected ones These finding was related to excessive loss of fat and protein which play an important role in accumulation of fluid in the tissue (edema) Mostafa and Yasein, (2010).

A highly significant increase in the $\mathrm{pH}$ values were demonostrated in Sarcocysts infected cattle compared to those of non infected cattle. These finding is partially due to an increase of moisture concentration and a weak muscular contraction as a result of parasitism. These weak muscular contraction due to formation of lactic acid by glycolysis (Robert et al., 1991).

From the previous results it could be concluded that parasitism with Sarcocysts increase the moisture percent and $\mathrm{pH}$ value, lower its protein and fat percentages. These serious effects greatly lower the meat quality and may render it completely unfit for consumption.

\section{Advise}

\section{From this study we can advise that:-}

- Prevent carnivore fecal contamination of bedding, feed and water.

- Dog and cats should be kept out of livestock housing and feed storage buildings.

- Prevented food animals from ingesting sporocysts stage which may present in contaminated bedding, feed and water.

- Prevent dogs/cats from eating uncooked meat

- Treatment with anticoccidial drugs (amprolium, salinomycin, halofuginone) may be attempted in the intermediate host

- Treatment is not necessary for the definitive host.

- Good personal hygiene such as hand washing with soap and water after handling raw meat.

- When such preventative measures cannot be assured and meat might be harboring cysts, it should be frozen for at least 2 days at $-20^{\circ} \mathrm{C}$ or thoroughly 
cooked at $70^{\circ} \mathrm{C}$ before consumption to kill infectious bradyzoites. These measures will prevent of intestinal stages where human might serve as definitive hosts (Fayer and Dubey, 1985; Srivastava et al., 1986 and Daryani et al., 2006).

\section{REFERENCE}

Alan, B. and Mac, J. (1996): Poultry meat hygiene and inspection. Ministry of Agriculture, Fisheries and Food. London, UK.

“AOAC" Association of Official Analytical Chemists (1980): Official Methods of Analysis $13^{\text {th }} \mathrm{Ed}$, Washington, DC.

Awad, Y.L. and Georgy, M.A. (1984): Some macro and micro elements in mutton meat under different health conditions. Egypt. J. Vet. Sci., 12: 57-64.

Daryani, A.; Alael, R.; Dehghan, M.N.; Arab, B.; Sharif, M. and Ziaei, H. (2006): Survey of Sarcocystis infection in slaughtered sheep and buffaloes in Aradabil, Iran. Jornal of animal and Vet. Advances 5 (1): 60-62.

Dubey, J.P.; Speer, C.A. and Fayer, R. (1989): "Sarcocystosis from animals and Man. Boca Raton. CRC Press, 215.

Dubey, J.P. and Lindsay, D.S. (1998): Sarcocystosis of animals and man. Boca Roton, Fla: IRC Pres. Inc., pp: 1-215.

Dubey, J.P.; Speer, C.A. and Epling, G.P. (1982): "Sarcocystosis in newborn calves fed Sarcocystis cruzi sporcysts from coyotes." Am. J. Vet. Res., 43: 2147-2164.

Dubey, J.P.; Spear, C.A. and Shah, H.L. (1989): Ultra structure of Sarcocysts form water buffalo in India. Vet. Parasitol., 34: 149-155.

El-Sayed, M. (2010): Studies on Sarcocystis speciesinfecting water buffaloes (Bubalus bubalis) in Egypt. M.V.Sc. Thesis (parasitology), Fac. Vet. Med., Khafer ElSheikh Univ., Egypt, 96PP.

Fayer, R. and Dubey, J.P. (1985): Method for controlling transmission of protozoon parasites from meat to man. Food Tech. 39(3): 57-60.

"FAO" Food and Agriculture Organization (1986): Manuals of food control. Via delle Tremadicaracalla, Rome, Italy.

Gabriele Ghisleni; Stefano Robba; Ottavia Germani and Eugenio Scanziani (2006): "Identification and prevalence of Sarcocystis spp. cysts in bovine canned meat". Food Control. 17 (9): 691-694.

Guclu, F.; Aldem-R, O.S. and Guler, L. (2004): Differential identification of cattle sarcocysosis spp. By random amplified polymerase chain reaction (RAPD-PCR). Revue Med. Vet., 155, 8-9: 440-444.

Herbert, I.V. and Smith, T.S. (1987): "Sarcocystosis". Parasitology Today3(1): 16-21.

Jae-Woong, Noh; Du-Hwan, J.; Yng-Bai, K.; Hawan, Jang and Sung-Hwan, W. (1988): "Effect of temperature on viability of Sarcocystis cruzi in cardiac musle of cattle". Kor. J. Vet. Pub. Hlth, 12(2).

Latif, B.M.A.; Al-Delemi, J.K.B.; Mohammed, S.; AlBayati, S.M. and Al-Amiry, A.M. (1999): "Prevalence of Sarcocystis spp. in meatproducing animals in Iraq, Veterinary ParasitologyVolume 166, Issues 3-4, 23.

Mostafa, N.Y. and Yasein, S.A. (2010): "Quality of Buffaloe's Meat Infected with Sarcocysts. Global Veterinaria 4 (4): 331-336.

Pearson, (1984): "Chemical Analysis of Food ". 8th Ed. Churchill Living Stone, Edinburgh, London.

Robert, K.; Peter, A.; Daryl, K. and Victor, $W$. (1991): Harper's biochemistry,26th Ed., Appleton and Lange, Norwalk, Connecticut, Los Altos, California USA.

Ronald, F. (2004): "Sarcocystis spp. in Human Infections" Clinical Microbiology Reviews . 17(4): . 894-902.

Soulsby, E.J.L. (1986): Helminths, athropods and protozoa of domesticated animals seventh edition, English language Book Society. William Clowes Ltd. Beccles and London.

Srivastava, P.S.; Saha, A.K. and Sinha, S.R.P. (1986): Effects of heating and freezing on the viability of sarcocysts of Sarcocystis levinei from cardiac tissues of buffaloes. Veterinary Parasitology. 19(3-4): 329-332

Vercruysse, J.; Fransen, J.; Van Goubergen, $M$. (1989): "The prevalence and identity of Sarcocystis cysts in cattle in Belgium. Zentralbl Veterinarmed B. 36(2): 148-53.

Yassien, M.A.M.; Soad A. Ismail and Amira A. Dessoki (2006): "Sarcocystosis in slaughtered cattle at Ismalia abattoirs." Alex. J. Vet. Sci. 24(1): 187-193.

\section{نسبة تواجد طفيل الساركوسست والتغيرات الكيميائية المصاحبة لة في لحوم الماشية في محافظة الاسكندرية أمانس فرج زايا ، كريية محد بكري ، ايناس عبد الرحمن حسن فراج}

بالر غم من أن لحوم الماثية من أهم مصادر البروتين الحيو انى وذلك لكثرة استخدامها من قبل الانسان. ولكن لسوء الحظ هناك انتشار واسع لطفيل

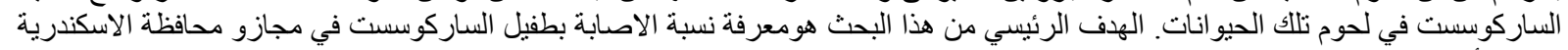

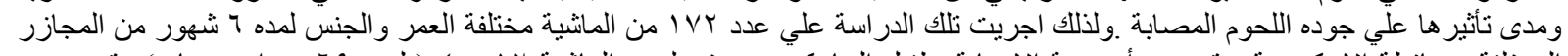

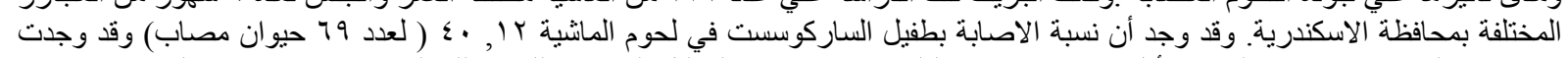

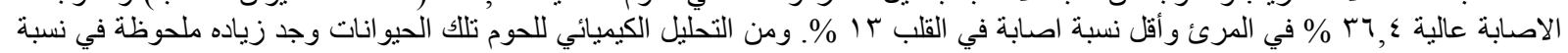

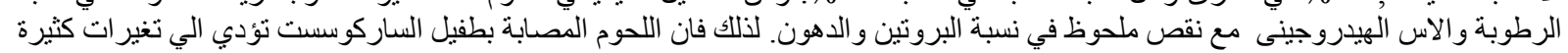

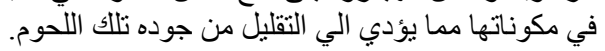

